\title{
The contribution of smallholder agriculture to the nutrition of rural households in a semi-arid environment in South Africa\#
}

\author{
W van Averbeke* and TB Khosa \\ Centre for Organic and Smallholder Agriculture, Department of Crop Sciences, Tshwane University of Technology, \\ Private Bag X680, Pretoria 0001, South Africa
}

\begin{abstract}
The contribution of own food production to the nutrition of households in two neighbouring, rural, semi-arid settlements was investigated. A survey of a $10 \%$ probability sample $(\mathrm{n}=131)$ of households in Sekuruwe and Ga-Molekane in the Mokgalakwena Local Municipality, Waterberg District Municipality, Limpopo Province, South Africa, conducted in 2001, provided data on household composition, income (cash and kind), poverty status, expenditure and agriculture, including a detailed account of the types and quantities of food that were purchased during the month preceding the date of the interview. For each household the food obtained from the different types of agriculture they practised was quantified. Protein, iron and Vitamins A and C were selected as indicators to assess the contribution of purchased and own produced food to the food intake of households. Food composition tables were used to estimate the nutrient content of the different foods. To assess the contribution of irrigated home gardening to food intake of households, Drum \& Drip micro-irrigation systems which enabled irrigated vegetable production on an area of $36 \mathrm{~m}^{2}$ were installed on the residential sites of 10 volunteer households in the study area. The results confirmed that income is the most important determinant of household food security in rural South Africa. However, food obtained from various types of dry-land agriculture contributed significantly to household nutrition and without farming the food security of households would be reduced, especially among the ultra-poor. Small-scale irrigated vegetable production was shown to have the potential to substantially raise the amount of the Vitamins A and C available to households but did not address the lack of protein in the diet of ultra-poor households and the lack of iron in the diet of all households.
\end{abstract}

Keywords: household food security, nutrition, poverty, rural agriculture, semi-arid, dry-land farming, irrigated home gardening, micro-nutrients, protein, iron, Vitamin A, Vitamin C

\section{Introduction}

The FAO (2003) defines household food security as 'access by all household members at all times to adequate, safe and nutritious food for a healthy and productive life'. About 35\% of the South African population is vulnerable to food insecurity (De Klerk et al., 2004). This type of vulnerability is most prevalent among black people who live on commercial farms or in the rural parts of the former homelands (De Klerk et al., 2004). In contemporary South Africa, income is the principal determinant of household food security (Kirsten et al., 2003). For monetary income South African Black rural households mainly depend on sources other than farming, including claims against the state, wage earnings, remittances by kin who live and work elsewhere, and petty trade (Carter and May, 1999; Crookes, 2003). On average, monetary income from farming typically contributes less than $10 \%$ to total household income. Households that have farming as their main source of monetary income are rare (May, 1996; Baber, 1996; Crookes, 2003; Monde, 2003). However, farming is not only a source of monetary income. It can also provide income in kind, in the form of food for home consumption, thereby enhancing household food security.

\# Revised version. Originally presented at the International Symposium on the Nutritional Value and Water Use of Indigenous Crops for Improved Livelihoods held on 19 and 20 September 2006 at the University of Pretoria in Pretoria, South Africa.

* To whom all correspondence should be addressed.

용 +2712 382-5777; fax: +2712 382-5869; e-mail: vanaverbekew@tut.ac.za
The strong link between household income and household food security in South Africa raises questions about the importance of small-scale agriculture in household food security, but few studies have investigated this relationship. Schmidt and Vorster (1995) determined whether or not participation in irrigated vegetable production on an $18 \mathrm{~m}^{2}$ plot improved the nutritional status of households, particularly among children, in a semi-arid setting in North-West Province but their results were inconclusive. Kirsten et al. (1998) related variables describing agricultural production of households in KwaZulu-Natal to the anthropometric data of children aged 0 to 60 months that formed part of these households. They found that agriculture improved the nutritional status of households, but only when production generated substantial monetary income, or when it enabled a substantial reduction in household food expenditure. The reason was that households involved in farming that met either or both of these conditions purchased larger quantities of energy-dense foods, such as fats, oils and meat and also more fruit and vegetables than households that did not farm or households of which the farming did not meet either of these two conditions. These results suggest that the main relationship between agriculture and nutrition is indirect and dependent on the contribution of agriculture to income. From their findings Kirsten et al. (2003) concluded that improving agricultural production as a strategy to alleviate poverty and enhance household food security needed to target areas where the natural resources were conducive to successful crop production. This conclusion raises doubts that small-scale food production in water-stressed environments contributes meaningfully to the nutrition of poor African households. 
This study investigated the contribution of own food production to the nutrition of households in two rural, semi arid settlements in the Limpopo Province.

\section{Materials and methods}

The study was conducted in Sekuruwe and Ga-Molekane, two neighbouring, semi-arid, rural settlements in the Mokgalakwena Local Municipality, Waterberg District Municipality, Limpopo Province, South Africa. The mean annual rainfall is about 580 $\mathrm{mm}$ and the annual reference crop evapotranspiration about $1800 \mathrm{~mm}$ (De Mey, 2002). The dominant soils are sandy $(>80 \%$ sand), shallow $(<500 \mathrm{~mm})$, stony and low in organic matter (less that 1\%) (De Mey, 2002).

The study used household as the unit of analysis. Household was defined as a unit of consumption and consisted of all the people who usually ate and slept under the same roof and who shared the same bundle of incomes to support their consumption. Income remitted to households by members who lived elsewhere was taken into account when determining household incomes, but these members were excluded from the households when determining their poverty status (AE) income and nutrient requirements.

A survey of a probability sample of 131 households, which constituted a 10\% sample of the 1226 households residing in the two settlements, was conducted in 2001 to provide data on household composition, income (cash and kind), expenditure and agriculture. The data included a detailed account of the types and quantities of food that were purchased during the month preceding the date of the interview. For each household the food obtained from the different types of agriculture being practised was quantified. In the case of home slaughtering of small and large livestock, estimates of the consumption of meat by the household concerned were based on the number of meals in which the household participated.

A poverty line constructed using the Household Subsistence Level for Polokwane determined by Potgieter (1999) was used to assess the poverty status of households. The poverty line was expressed per AE using the method developed by Carter and May (1999) to account for household composition and to enable comparison among households. Protein, iron, Vitamin A and Vitamin C were selected as indicators to assess the contribution of purchased and own-produced food to the nutrition of households. The food composition tables of Wolmarans et al. (1992) and Burgess et al. (1998) were used to estimate the nutrient contents of the different foods. Protein was selected as an indicator of PEM (protein and energy malnutrition) and the other three nutrients as indicators of hidden hunger (Amissah, 2000). To assess the contribution of the different foods to household nutrition, the recommended daily allowance (RDA) for each of the four nutrients was calculated for the individual members of each household, using the guidelines of Burgess et al. (1998), which take age and gender into account. For each household the RDA of the individual members were added together to obtain the daily household requirement for each of the four nutrients. For the different poverty categories the mean daily household requirement for the four nutrients was the mean of the individual daily household requirements of all the households in each of these categories.

To assess the contribution of irrigated home gardening to food intake of households, drum- and-drip micro-irrigation systems (Khosa et al., 2003), which enable irrigated vegetable production over an area of $36 \mathrm{~m}^{2}$, were installed on the residential sites of 10 volunteer households in the study area. The fertility of the soil in these plots was raised at the time of planting on 1 August 2000 by applying the chemical fertiliser mixture 2:3:2 (25) at the rate of $500 \mathrm{~kg} \cdot \mathrm{ha}^{-1}$. In each plot the fertiliser mixture was uniformly spread by hand in 6 parallel furrows which were spaced $1 \mathrm{~m}$ apart and were opened using a hand hoe. The fertiliser, which added nitrogen at the rate of $37.5 \mathrm{~kg} \mathrm{~N} \cdot \mathrm{ha}^{-1}$, phosphorus at the rate of $53.6 \mathrm{~kg} \mathrm{P} \cdot \mathrm{ha}^{-1}$ and potassium at the rate of 37.5 $\mathrm{kg} \mathrm{K} \cdot \mathrm{ha}^{-1}$ to the soil in the plots, was incorporated in the soil by running the handle of a rake along the bottom of the furrows. The gardens were planted with cabbages, Swiss chard, onions, beetroot, pumpkins, tomatoes, carrots and green peppers using transplants obtained from a commercial nursery. Each participant was supplied with a mechanical food scale with an accuracy of $20 \mathrm{~g}$ and a diary to record the mass of fresh produce harvested from the garden during a 4-month period.

The following simplifying assumptions were introduced in the analysis of the data:

- The monthly purchase of food by the individual households was considered constant throughout the year. This assumption is probably reasonably valid. In the Eastern Cape, Monde (2003) found that household food purchases were fairly constant throughout the year but the amounts and nutritional quality of the food that was purchased in December were higher than those recorded in March, June and September.

- The food obtained from the various types of dry-land farming and from irrigated home gardening was considered uniformly available throughout the year. In the Eastern Cape, Monde (2003) found that rural household consumption of own-produced food tended to be seasonal. Intake of vegetables, tubers, and milk was highest in summer and autumn. The intake of cereals was less seasonally bound. Thus, there may be some doubt about the validity of this assumption.

- All food was considered uniformly available to the individual household members in proportion to their gender and age-based nutritional requirements. This assumption is probably valid except for the meat of animals slaughtered for ritual purposes of which adult males proportionally consume more than women and children (Wenhold et al., 2007).

- The selected nutrients contained in the different foods were considered to be fully bio-available. Burgess et al. (1998) warn that the human body absorbs less carotene from green leafy vegetables than has been assumed and that absorption of non-haem iron found in plant foods through the gut may be limited to $5 \%$ of the total iron content of these foods, whereas absorption of haem iron found in the blood and muscle of animals is approximately $25 \%$ of their total iron contents. Thus, this assumption is probably not valid.

- The produce harvested from the irrigated home gardens during the 4-month period was taken to represent one-third of the amount that could be harvested during a full year of production. A similar assumption was made by Schmidt and Vorster (1995) and when season is taken into account in the selection of vegetables this assumption is probably valid.

\section{Results and discussion}

The poverty line at the time of the survey was R413.11·AE $\mathrm{A}^{-1} \cdot \mathrm{month}^{-1}$. Households with incomes that exceeded the poverty line were categorised as non-poor and those with incomes less than the poverty line as poor. The category of the poor was subdivided further into poor and ultra-poor. Ultra-poor households had incomes of less than half the poverty line, i.e. less than R206.56 $\cdot \mathrm{AE}^{-1} \cdot \mathrm{month}^{-1}$. Mean total monthly household income 


\begin{tabular}{|c|c|c|c|}
\hline \multicolumn{4}{|c|}{$\begin{array}{c}\text { TABLE } 1 \\
\text { Mean total income, adult equivalent income and } \\
\text { size of household by poverty category } \\
\text { (Sekuruwe and Ga-Molekane, 2001; } n=131 \text { ) }\end{array}$} \\
\hline $\begin{array}{l}\text { Household poverty } \\
\text { status }\end{array}$ & $\begin{array}{c}\text { Mean total } \\
\text { household } \\
\text { income }\end{array}$ & $\begin{array}{l}\text { Mean } \mathrm{AE}^{2} \\
\text { income }\end{array}$ & $\begin{array}{c}\text { Mean } \\
\text { household } \\
\text { size }\end{array}$ \\
\hline & \multicolumn{3}{|c|}{$\left(\mathrm{R}^{2}\right.$ month $\left.^{-1}\right)$} \\
\hline Non-poor $(n=30)$ & 1022.16 & 644.43 & 5.4 \\
\hline Poor $(n=48)$ & 1048.24 & 288.41 & 5.7 \\
\hline Ultra-poor $(n=53)$ & 821.91 & 132.76 & 7.7 \\
\hline
\end{tabular}

\begin{tabular}{|l|c|c|c|c|}
\hline \multicolumn{5}{|c|}{$\begin{array}{c}\text { TABLE 2 } \\
\text { Average daily household requirement of } \\
\text { selected nutrients by poverty category } \\
\text { (Sekuruwe and Ga-Molekane, 2001; n=131) }\end{array}$} \\
\hline $\begin{array}{l}\text { Household } \\
\text { poverty status }\end{array}$ & \multicolumn{2}{|c|}{ Average daily household requirement } \\
\cline { 2 - 5 } & Protein & Iron & Vitamin A & Vitamin C \\
\hline Non-poor & $\mathbf{( g )}$ & $\mathbf{( m g )}$ & (mcg Re) & (mcg) \\
\hline Poor & 169.03 & 98.90 & 1678.33 & 96.33 \\
\hline Ultra-poor & 244.46 & 143.85 & 2436.46 & 136.88 \\
\hline
\end{tabular}

${ }^{1}$ total household income included cash and kind;

${ }^{2} \mathrm{AE}=$ adult equivalent

TABLE 3

Differences in the types of food purchased by households in three poverty categories (Sekuruwe and Ga-Molekane, 2001; $n=131$ )

\begin{tabular}{|l|l|l|l|}
\hline Food group & $\begin{array}{l}\text { Ultra-poor } \\
\mathbf{( n = 5 3 )}\end{array}$ & $\begin{array}{l}\text { Poor } \\
(\mathbf{n}=\mathbf{4 8})\end{array}$ & $\begin{array}{l}\text { Non-poor } \\
(\mathbf{n}=\mathbf{3 0})\end{array}$ \\
\cline { 3 - 4 } & $\begin{array}{l}\text { Additions to food purchased by ultra-poor } \\
\text { households }\end{array}$ & $\begin{array}{l}\text { Additions to food } \\
\text { purchased by } \text { poor } \\
\text { households }\end{array}$ \\
\hline Cereals & Maize meal, wheat flour & Stamp maize, rice, bread & None \\
\hline Pulses & Dry beans & Canned beans in tomato sauce & None \\
\hline Animal products & White and red meat, canned fish & Sour milk, fresh milk, eggs & Fresh fish \\
\hline Fruit & Oranges & Bananas, apples, mangoes & None \\
\hline Vegetables & $\begin{array}{l}\text { Cabbages, onions, tomatoes, } \\
\text { potatoes }\end{array}$ & None & $\begin{array}{l}\text { Beetroot, pumpkins } \\
\text { and sweet potatoes }\end{array}$ \\
\hline Fats & Cooking oil & Margarine, mayonnaise & None \\
\hline Other & Soup, coffee, tea, sugar, salt & Jam, peanut butter, milk powder, tomato ketchup & None \\
\hline
\end{tabular}

did not differ much among the three poverty classes but mean monthly AE incomes differed vastly, indicating that household composition (mainly size) was the critical factor determining poverty status (Table 1 ).

Differences in mean household size among the poverty categories also affected the mean daily household requirements for the four nutrients (Table 2). On average, the nutrient requirements of ultra-poor households were more than double those of non-poor households.

The proportional expenditure of households on food was closely related to their AE income and therefore their poverty status. Figure 1 shows that proportional expenditure on food rose sharply when AE income dropped below about R400, which was more or less equal to the poverty line.

The types of food households purchased were associated with their poverty status (Table 3). Poor and especially non-poor households showed greater variety in their diet than ultra-poor households, by adding energy-dense foods, such as dairy products, margarine and mayonnaise and also fresh fruit and vegetables. This is in line with the findings of Kirsten et al. (2003).

Poverty status also affected the extent to which purchased food was able to satisfy the requirements of the selected nutrients among households (Table 4 - next page). On average, the food purchased by non-poor and poor households contained sufficient protein and Vitamin $\mathrm{C}$ to satisfy their requirements. The Vitamin A content of purchased food was insufficient to meet the requirements of the poor households and the iron content was not enough to meet the requirements of both the non-poor and the

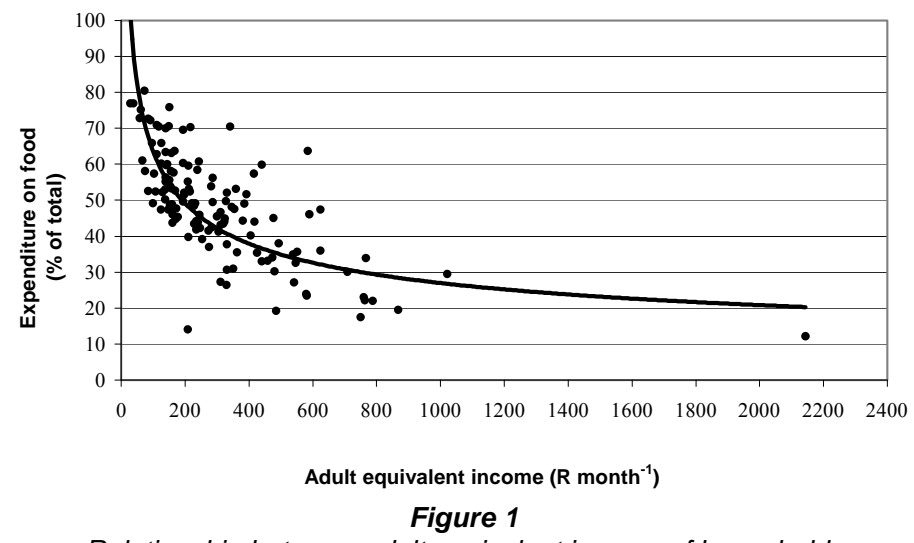

Relationship between adult equivalent income of households and the proportion of their total expenditure spent on the purchase of food at Sekuruwe and Ga-Molekane in $2001(n=131)$

poor households. The food purchased by the ultra-poor households was inadequate to meet their requirements for all four nutrients.

Four different types of dry-land farming were identified in the study area, namely home gardening, field cropping, micro-livestock production (poultry and pigs) and the production of small (sheep and goats) and large livestock (cattle). The mean total amounts of the selected nutrients that were obtained from these farming activities or combinations thereof are shown in Table 5 (next page).

For all four nutrients involvement in multiple farming activities tended to increase the quantities that were obtained from agriculture, but differences were smaller than expected. On average, the amounts of nutrients in food produced by engaging in three or four farming activities were only about 2.5 to 2.7 times higher than the food obtained 


\begin{tabular}{|c|c|c|c|c|}
\hline \multicolumn{5}{|c|}{ 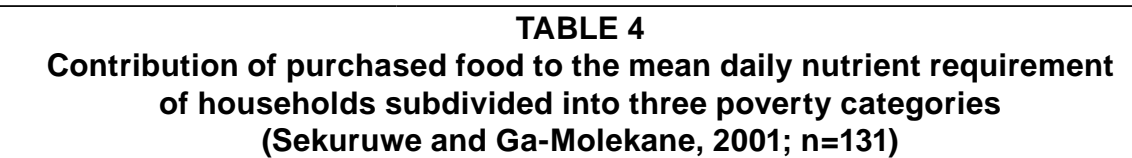 } \\
\hline \multirow[t]{2}{*}{ Household poverty status } & \multicolumn{4}{|c|}{$\begin{array}{c}\text { Contribution of purchased food to mean daily } \\
\text { household requirement (\%) }\end{array}$} \\
\hline & Protein & Iron & Vitamin A & Vitamin C \\
\hline Non-poor & 134 & 34 & 65 & 201 \\
\hline Poor & 98 & 22 & 23 & 98 \\
\hline Ultra-poor & 52 & 12 & 9 & 53 \\
\hline
\end{tabular}

\begin{tabular}{|c|c|c|c|c|}
\hline \multicolumn{5}{|c|}{$\begin{array}{c}\text { TABLE } 5 \\
\text { Mean total amounts of selected nutrients contained in the food that } \\
\text { was obtained from different types of dryland farming by households } \\
\text { in Sekuruwe and Ga-Molekane during the period October } 2000 \text { to } \\
\text { September } 2001(n=131)\end{array}$} \\
\hline \multirow[t]{2}{*}{ Type of farming } & \multicolumn{4}{|c|}{ Total nutrient content of the foods obtained and consumed } \\
\hline & $\begin{array}{c}\text { Protein } \\
\text { (g) }\end{array}$ & $\begin{array}{l}\text { Iron } \\
\text { (mg) }\end{array}$ & $\begin{array}{c}\text { Vitamin A } \\
(\mu \mathrm{g} \mathrm{Re})\end{array}$ & $\begin{array}{c}\text { Vitamin C } \\
(\mathrm{mg})\end{array}$ \\
\hline $\mathrm{HG}$ & 6635 & 3103 & 248036 & 14139 \\
\hline HG \& FC & 12992 & 5096 & 443200 & 24834 \\
\hline HG\& ML & 8781 & 4249 & 291242 & 19080 \\
\hline HG \& ML\& S\&LL & 9693 & 4376 & 352240 & 17693 \\
\hline $\mathrm{HG} \& \mathrm{FC} \& \mathrm{ML}$ & 13482 & 4925 & 439619 & 24109 \\
\hline HG \& S\&LL & 8171 & 3475 & 258209 & 15346 \\
\hline HG \& FC \& S\&LL & 16329 & 7452 & 608851 & 37780 \\
\hline All four types & 15148 & 6034 & 521088 & 27244 \\
\hline
\end{tabular}

$H G=$ home gardening; $F C=$ field cropping; $M L=$ micro-livestock production (poultry and pigs);

$S \& L L=$ small and large livestock production (cattle, goats and sheep).

by dry-land home gardening only (Table 5). Reasons for these smaller than expected differences were that:

- Households that limited their farming to home gardening tended to farm their gardens more intensively than those engaged in home gardening and field cropping, suggesting a degree of compensation.

- All households involved in micro-livestock production employed a scavenging system, which is known for its low productivity (Smith, 1990; Holness, 1991).

- The grain harvests obtained from field cropping during the 2000-01 season were low, but reportedly this was the rule rather than the exception in the study area, mainly because of water deficits during the growing season of the crops.
- Nearly all of the milk produced by cattle and goats was left to the calves and kids, because successful livestock reproduction was the primary farmer objective.

- Without exception home slaughters of small or large livestock formed part of ceremonies in which large numbers of people participated, limiting the nutritional benefit accruing to the farming household.

The rate of participation of households in the different types of agriculture was similar across the three poverty categories, perhaps with one exception, namely that ultra-poor households tended to participate less in field cropping than others (Fig. 2).

Differences in the mean contribution of dry-land farming to the nutrient requirements of households among the poverty

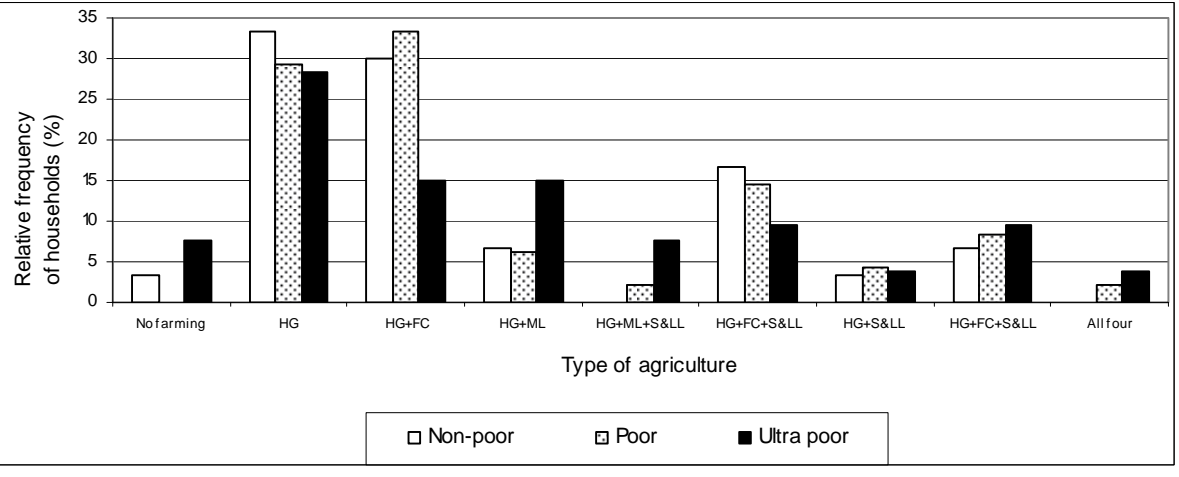

$H G$ = home gardening; $F C=$ field cropping; $M L=$ micro-livestock production (poultry and pigs); $S \& L L=s m a l l$ and large livestock production (cattle, goats and sheep). For each poverty category the proportion of households (\%) involved in the different types of agriculture is shown.
Figure 2

Participation of households in different types of agriculture by poverty category (Sekuruwe and Ga-Molekane, 2001, $n=131$ ) 


\begin{tabular}{|c|c|c|c|c|}
\hline \multicolumn{5}{|c|}{$\begin{array}{l}\text { TABLE } 6 \\
\text { Contribution of food obtained from different types } \\
\text { of dry-land farming to the mean daily nutrient } \\
\text { requirement of households by poverty category } \\
\text { (Sekuruwe and Ga-Molekane, 2001; } n=131 \text { ) }\end{array}$} \\
\hline \multirow[t]{2}{*}{$\begin{array}{l}\text { Household } \\
\text { poverty status }\end{array}$} & \multicolumn{4}{|c|}{$\begin{array}{c}\text { Contribution of food obtained from dry- } \\
\text { land farming to mean daily household } \\
\text { requirement (\%) }\end{array}$} \\
\hline & Protein & Iron & Vitamin A & Vitamin C \\
\hline Non-poor & 25 & 15 & 71 & 60 \\
\hline Poor & 17 & 10 & 49 & 42 \\
\hline Ultra-poor & 12 & 8 & 35 & 29 \\
\hline
\end{tabular}

categories (Table 6) were largely explained by the differences in the mean household nutrient requirements resulting from differences in mean household size (Tables 1 and 2). These results suggest that in the study area own food production was not associated with poverty status.

Generally, dry-land farming made a modest contribution to the protein and iron requirements of households, but its contribution to meeting the Vitamin A and Vitamin C requirements of households was substantial and of particular importance for ultra-poor households.

The results of monitoring production in the irrigated home garden plots indicated that this practice had the potential to contribute significantly to the Vitamin A and $\mathrm{C}$ requirements of households in all three poverty categories, but its contribution to the protein and iron requirements was very limited (Table 7).

In the analysis of the data food obtained from own production was taken as having no influence on food purchases. In a study in the Eastern Cape, Monde (2003) provided evidence of a relationship between the availability of own-produced food and food purchases. She found that during the period that own-produced food was available, households tended to reduce their food purchases, particularly in terms of staple foods, such as maize products. Money saved in this way was then available to satisfy needs that were not necessarily food related. Similar results were obtained by Tapson et al. (1986) in Ndombeni near Hluhluwe in northern KwaZulu-Natal. They reported that households that were less than $25 \%$ self-sufficient in terms of staple food production spent about equal amounts per household member per month as households that were more than $75 \%$ self-sufficient. However, among the low food self-sufficiency group an average of $83 \%$ of expenditure was on purchasing food, whereas the high food self-sufficiency group spent on average only $57 \%$ of their total expenditure on food. This confirms that households in the high food self-sufficiency group have more money available for 'discretionary' expenditure. Evidence from Ndombeni was that households with high levels of food self-sufficiency typically owned 'luxury' items, such as bicycles and radios, whereas the households with low levels of food self-sufficiency did not (Tapson et al., 1986).

\section{Conclusions}

The findings of this study confirmed the importance of household income (measured as AE income) as a factor in household food security in contemporary rural South Africa and the positive relationship between household income and the purchase of energy-dense foods, fruit and vegetables identified in other studies. The data collected in the present study could not be used to determine whether or not own-produced food replaced purchased food but for the nutrients that were investigated, the food
TABLE 7

Estimated contribution of vegetable production in irrigated home gardens to the average nutrient requirements of households by poverty category (Sekuruwe and Ga-Molekane, 2001)

\begin{tabular}{|l|c|c|c|}
\hline \multirow{2}{*}{ Nutrient } & $\begin{array}{c}\text { Non-poor } \\
(\mathbf{n = 3 0 )}\end{array}$ & $\begin{array}{c}\text { Poor } \\
(\mathbf{n}=\mathbf{4 8})\end{array}$ & $\begin{array}{c}\text { Ultra-poor } \\
(\mathbf{n}=\mathbf{5 3})\end{array}$ \\
\cline { 2 - 4 } & \multicolumn{4}{|c|}{$\begin{array}{c}\text { Contribution to mean daily household } \\
\text { requirement (\%) }\end{array}$} \\
\hline Protein & 3.2 & 2.2 & 1.6 \\
\hline Iron & 5.9 & 4.1 & 3.0 \\
\hline Vitamin A & 37.8 & 26.1 & 18.3 \\
\hline Vitamin C & 34.3 & 24.1 & 16.7 \\
\hline
\end{tabular}

households obtained from various types of dry-land agriculture contained large enough quantities of nutrients to contribute significantly to satisfying the requirements of households. Other research has shown that smallholder farming mainly improves household nutrition indirectly by availing money for the purchase of energy dense foods, fruit and vegetables, either through sales of produce or through saving on food expenditure. Some studies even raise doubts about the indirect contribution of smallholder farming to household nutrition by pointing out that savings on food expenditure through own-production of food is not necessarily spent on the purchase of high quality food but also on non-food items. The present study did provide evidence of a direct relationship between food production and household nutrition in terms of micronutrient intake. In Sekuruwe and Molekane, fresh produce in the form of vegetables and fruit produced or collected from the wild were largely additions to the diet, not replacements of food that was otherwise purchased. Monitoring of the irrigated home gardens showed that small-scale irrigated vegetable production had the potential to substantially raise the amount of the Vitamins A and $C$ available to households. Consequently, this particular type of farming has the potential to directly improve household nutrition, especially among the ultra-poor, but not comprehensively, because it failed to address the lack of protein in the diet of ultra-poor households and the lack of iron in the diet of all households.

\section{Acknowledgements}

This article is based on work that was supported by the Tshwane University of Technology and the National Research Foundation, but the authors accept full liability for any opinions, findings, conclusions or recommendations contained in this paper.

\section{References}

AMISSAH A (2000) Inadequate Dietary Intakes as a Cause of Stunting Among Young Children in Rural South Africa. M. Tech. dissertation, Technikon Pretoria, Pretoria. 239 pp.

BABER R (1996) Current livelihoods in semi-arid rural areas of South Africa. In: Lipton M, Ellis F and Lipton M (eds.) Land, Labour and Rural Livelihoods in South Africa (Vol. 2): KwaZulu-Natal and Northern Province. Indicator Press, Durban. 269-302.

BURGESS A, MAINA G, HARRIS P and HARRIS S (1998) How to Grow a Balanced Diet: A Handbook for Community Workers. VSO Books, London. 229 pp.

CARTER M and MAY J (1999) Poverty, livelihoods and class in rural South Africa. World Dev. 27 (1) 1-20.

CROOKES D (2003) The contribution of livelihood activities in the Limpopo province: case study evidence from Makua and Manganeng. Dev. South. Afr. 20 (1) 143-159. 
DE KLERK M, DRIMIE S, ALIBER M, MINI S, MOKOENA R, RANDELA R, MODISELLE S, VOGEL C, DE SWARDT C and KIRSTEN J (2004) Food security in South Africa: Key policy issues for the medium term [Online]. Available from: http://www.sarpn. org.za/documents/d0000685/Food_security_SA_January 2004.pdf (Accessed on 12/06/2006).

DE MEY K (2002) Gebruik en Invloed van Kraal Mest op de Fysische Bodemvruchtbaarheid in de Landelijke Gebieden van de Noordelijke Provincie (Zuid-Afrika). Bio-engineer dissertation. Ghent University, Ghent. 172 pp.

FAO (FOOD AND AGRICULTURE ORGANIZATION OF THE UNITED NATIONS) (2003) Trade Reforms and Food Security. Commodity Policy and Projection Service of the Commodities and Trade Division, FAO, Rome. 315 pp.

HOLNESS DH (1991) Pigs. The Tropical Agriculturalist Series. MacMillan Education Ltd, London. 150 pp.

KHOSA TB, VAN AVERBEKE W, BÖHRINGER R and ALBERTSE E (2003) Drum \& drip system for rural households. SA Irrigation 25 (3) 9-11.

KIRSTEN J, MAY J, HENDRIKS S, LYNE M, MACHETE C and PUNT C (2003) The poverty and food security role of agriculture. Paper prepared for the Roles of Agriculture International Conference, 22-23 October, 2003, Rome, Italy: Agricultural and Development Economics Division (ESA) of the Food and Agriculture Organization (FAO) of the United Nations. $61 \mathrm{pp}$.

KIRSTEN J, TOWNSEND R and GIBSON C (1998) Determination of agricultural production to household nutritional status in KwaZuluNatal, South Africa. Dev. South. Afr. 15 (4) 573-587.
MAY J (1996) Assets, income and livelihoods in rural KwaZulu-Natal. In: Lipton M, Ellis F and Lipton M (eds.) Land, Labour and Rural Livelihoods in South Africa (Vol.2): KwaZulu-Natal and Northern Province. Indicator Press, Durban. 1-30.

MONDE N (2003) Household Food Security in Rural Areas of Central Eastern Cape: The Case of Guquka in Victoria East and Koloni in Middledrift Districts. Ph.D. thesis, University of Fort Hare, Alice. 263 pp.

POTGIETER JF (1999) The Household Subsistence Level in the Major Urban Centres of the Republic of South Africa (September 1999). Fact Paper No 107. Institute of Planning Research, University of Port Elizabeth, Port Elizabeth. 54 pp.

SCHMIDT MI and VORSTER HH (1995) The effects of communal gardens on nutritional status. Dev. South. Afr. 12 (5) 713-725.

SMITH AJ (1990) Poultry. The Tropical Agriculturalist Series. MacMillan Education Ltd. London. 218 pp.

TAPSON DR, LAKER MC and BEMBRIDGE TJ (1986) The Ndombeni Survey. Unpublished report. ARDRI, Univ. Fort Hare, Alice. 40 pp.

WENHOLD FAM, FABER M, VAN AVERBEKE W, OELOFSE A, VAN JAARSVELD P, JANSEN VAN RENSBURG W, VAN HEERDEN I and SLABBERT R (2007) Linking Smallholder agriculture and water to household food security and nutrition. Water SA 33 (Special edition) 327-336.

WOLMARANS P, LANGENHOVEN M and FABER, M (1992) Food: Facts and Figures, the Complete South African Guide. Oxford University Press, Cape Town. 135 pp. 